\title{
The Challenges Facing the Effective Implementation of Drought and Desertification Policy in North-East Geo-political Zone of Nigeria
}

\section{Chibueze Okeoma Nwokocha*}

Political Science and Public Administration, Babcock University, Ilishan Remo, Ogun State, Nigeria

*Corresponding author: Nwokocha CO, Political Science and Public Administration, Babcock University, Ilishan Remo, Ogun State, Nigeria, Tel: 2348066854892; Email: okaysimoh@gmail.com

Received date: July 04, 2017; Accepted date: July 25, 2017; Published date: July 31, 2017

Copyright: (c) 2017 Nwokocha CO. This is an open-access article distributed under the terms of the Creative Commons Attribution License, which permits unrestricted use, distribution, and reproduction in any medium, provided the original author and source are credited.

\begin{abstract}
This paper examined the challenges around the effective implementation of strategies put in place by Nigerian government to combat the twin menace of drought and desertification the North-east geo-political zone of Nigeria. It then proffered solutions to the challenges as established from the survey carried out in the zone.

The introduction to the subject under discuss reviewed the extent to which the twin phenomenon were ravaging the zone and efforts of government so far which has not yielded the expected results. The study adopted the survey design approach. Population of the study was the North-east geo-political zone of Nigeria comprising six states: Adamawa, Borno, Bauchi, Gombe, Taraba and Yobe. Purposive sampling technique was used in the selection of sample size comprising of six local councils from Adamawa, Bauchi and Gombe states; the reason being that they share common characteristics on the challenges of drought and desert encroachments. Cluster sampling technique was adopted in selection of 1,200 respondents of which $72.6 \%$ response rate was recorded. The research instrument used was a structured and validated questionnaire complemented by a structured interview schedule.

The study finding the following challenges: Poor funding of government programs, Government field agents not managing the trees planted in other to productively achieve its set objective, citizens mismanagement of facilities put in place by government to curb the menace, indiscriminate falling of trees planted by government, sparse rain fall experienced in region.

The study, thus recommended that to curb the challenges of implementation the following must be considered: citizen participation at the implementation stage of every project initiated by government to curb these menace. The public must be Educated government actions and strategies, An alternative to firewood for cocking in the zone must be provided, a special joint taskforce of federal, state and local are policing of the forests must be put in place as a matter of urgency to check the indiscriminate falling of the trees also effective monitoring and evaluation of the activities of government agents deplored to implement these strategies must be put in place.
\end{abstract}

Keywords: Drought; Desertification; Communities; Geo-political

\section{Introduction}

An area of environmental concern that has posed serious challenges to human societies living in most of the states in the Northern part of Nigeria and which has consistently threatened the harmony of the ecosystem in these states is the combined effect of drought and desertification. An area of environmental concern which scholars suggest, poses a serious threat to any form of sustained socio-economic development.

Nigeria, is located between latitudes $4^{\circ} \mathrm{N}$ and $14^{\circ} \mathrm{N}$ and longitudes $2^{\circ} 2^{\prime}$ and $14^{\circ} 30^{\prime}$ east has a total land area of $923,773 \mathrm{~km}^{2}$ and a population of over 100 million. In the north, the country is bordered by the Republics of Niger and Chad Republics; the Atlantic Ocean border it to the south while the Republics of Cameroon and Benin border the country to the east and west, respectively. With regard to its spatial layout, the country incorporates a range of climatic regimes and physiographical units that constitute a variety of ecological zones. They include: flush forest vegetation in the south to Guinea savanna in the middle belt region, Sudan savanna in the north and sahelian vegetation in the far north. Sudan and sahelian regimes are the most vulnerable of these zones to climatic and human pressures [1].

The Sudan and the Sahelian savanna make up the semi-arid areas with low rainfall land sparse vegetation. They lie within latitudes $120 \mathrm{~N}$ and $140 \mathrm{~N}$. Averagely, annual rainfall in these zones varies from as low as $250 \mathrm{~mm}$ in the far north eastern part to $750 \mathrm{~mm}$ in the southern part. Rainfall in the northern region is largely erratic. The southern parts are usually humid, while the middle belt has moderate rainfalls with derived vegetation as well as sub-humid. There are also variations in the geology and soil types of the zones. The characteristic of the semi-arid zone is susceptible to desertification process, and at the same time constitutes largest grain producing area of the country. There is also the fact that most of the live stocks in Nigeria emanate from this area. In a year of generous rainfall, the zone rewards human efforts with bountiful agricultural yields and livestock production. Inversely, in the years of sparse rainfall, grain and livestock production is adversely affected resulting in food deficits and other social and economic consequences [1].

Mohammed [2] suggests that it is not unlikely that human attempts to exploit the resources of the semi-arid ecosystems of Nigeria, 
especially in recent times of severe and persistent drought and its concomitant desertification, may have enhanced the rate of ecological damage in the region. The situation is being aggravated by the increase in human population, which brings additional stress to bear on the lean natural support system. In many areas sustainable-yield threshold of the vegetation and soils are being breached.

Desertification, which is affecting 11 of the northern States, is considered as the most pressing environmental problem and accounts for about $73 \%$ out of the estimated total cost of about US $\$ 5.110$ billion per annum the country is losing to environmental degradation. Shehu laments that the worst hit by this situation are some states in the North-East. The situation in Yobe State indicates that, productive and mass land occupied by the dunes in the state has increased from 25000 hectares to more than 30,000 hectares with its attendant negative impact on food and livestock production. More than five million livestock in Yobe State are under serious threat due to the deterioration of pastures occasioned by seasonal droughts and desert encroachment. A report by Adamawa State Ministry of Agriculture in 1994 indicated that more than 15,000 hectares of land in the state suffered from serious desertification related problems [3].

Emodi [4] while looking at desertification and erosion as a dual effect of deforestation stated that "Borno state communities such as Bulatura, Kaska, BukartyToshu, Tubtulova, Yunusari, among others, have been either completely surrounded by sand dunes or are about to be buried by them. There is also the fact that people of the state have been moving southwards to areas around Gashua, Nguru, Kukuna, Monguno, of which themselves are within the fragile environment".

Shehu, examined the efforts of government over the years which include: enactment of enabling policies, tree planting, creation of dams to irrigate drought affected areas in the north and the establishment of River Basin Authorities to manage such dams opined that these interventions have not been very effective. Indeed, the damage done by human activities and natural conditions in northern Nigeria seem to have lost solutions over the years creating thought as to the implementation abilities of government and her relevant agencies toward the combating of drought and desertification challenges. Shehu is not alone in his opinion, following the comments of the Minister of Environment Mrs. Laurentia Laraba Malam, in a welcome address on the occasion of the 3rd Northern Stakeholders Forum/Zonal Ecofair in Lokoja, lamented that: "Despite huge commitment by Northern States and the Federal Governments on issues of drought and desertification in the North, the result has not been commensurate with resources expended" [5].

This research work therefore examines reason for the perceived ineffectiveness or failure of government activities at the implementation of drought and desertification policy in the north-east geo-political zone. It then recommends the solutions to government and indeed the people of Nigeria to bring about a lasting control measure to the challenges of drought and desertification.

\section{Statement of the problem}

Drought and Desertification is one of the major environmental challenges plaguing Nigeria, and have apparently defied intervention efforts by various governments of Nigeria. It is estimated that Nigeria is currently losing about 351,000 hectares of its landmass over rampaging desert conditions annually, and such conditions are advancing southwards at the rate of about $0.6 \mathrm{~km}$ per year [6]. The situation according to Shehu, it seems to be worst in the North-east geo-political zone where, in Yobe State, producing and mass land occupied by sand dunes has increased from 25,000 hectares to more than 30,000 hectares and continuing.

The efforts of successive Nigerian governments to control the menace seem to have been unyielding. In 1989, Nigerian Government in the bid to tackle environmental challenges ravaging the country developed a policy on environment titled National Policy on Environment (NPE). The policy document took care of all areas of environmental challenges including the issues of drought and desertification. In pursuant to a successful implementation of this aspect of the environmental policy, Nigerian Government also signed up to the convention on combating desertification (CCD) in 1995. However, since the policy came into existence, the challenge of drought and desertification has continued to degrade the Nigerian environment, especially North-east geo political zone of the country.

Thus the implementation processes of government raises questions since they show ineffectiveness or outright failure. The research is designed to specially examine the prescriptions of the policy toward combating the twin menace. The focus is to establish the perceived challenges leading to the failure or infectiveness of drought and desertification policy implementation in the North-east geo-political zone of Nigeria.

\section{Objective of the Study}

The main objective of this study is to identify the challenges facing the effective implementation of drought and desertification policy in the North-east geo-political zone. The study is also concerned with proffering solution to the identified challenges.

\section{Research Questions}

- What are the Policy implementing strategies put in place by Nigeria government to Drought and Desertification in the Northeast?

- Are there challenges facing the effective implementation of drought and desertification policy in the North-east geo-political zone?

- What are the possible solutions to these challenges?

\section{Scope of the Study}

This study was conducted in the North-East geo-political zone of Nigeria. The period covered by the study was 10 years (2004-2014). This reorganized the UN convention which Nigeria adopted in 1995 and was rectified in December, 2000. Thus, taking cognizance of the mandatory 3 years gestation period, any meaningful examination of challenges faced by government at implementing the policies aimed at combating drought and desertification would have to start from 2004. The research was conducted focusing on three states out of the six states of the North-east geo-political zone of the country; the reason was based on issues of insurgency situation in the North-East Geopolitical zone of Nigeria.

\section{Theoretical considerations}

The subject matter was focused on finding reasons why the policy on drought and desertification have failed at its implementation. Consequently, assist in finding proper solutions to the continuous challenges of drought and desertification in North-east geo-political 
zone of Nigeria. The assumption was that the drought and desertification policy was deficient. Thus the research adopted the topdown theory to establish (1) If there is a relationship between the assumed failure of the policy to effectively check the challenges of drought and desertification in the North-east and the fact that it is centrally made policy. (2) Are there linear relationship between agreed policy goals and their implementation? (3) Is adequate bureaucratic procedures put in place to ensure that policies are executed as accurately as possible (4) What implementing agencies are involved and do they have sufficient resources at their disposal? (5) What clear responsibilities and hierarchical control are there to supervise the actions of implementers?

The second assumption was that implementers of the policy on drought and desertification are bureaucrats, thus adoption of bottomup theory, to be able to establish the possibility that although the policy is centralized, bureaucrats are allowed to take initiative on the policy at the local level, involving the indigenes of affected communities, in delivering policy goals and that ineffective supervision of their activities could be the reason for continuous degradation of the environment by the drought and desertification [7].

The third assumption was that both policy makers and implementers (bureaucrats) will need to identify their roles in the strategies as laid down in the policy and apply it religiously without the hierarchical bottle necks that tend to affect optimal service. Above all there is the need to network effectively across board especially at the point of initiating action plan to implement the strategies established by the policy. Hence the research adopted the hybrid implementation theory.

Finally the research settled on the third assumption, with the conclusion that no meaningful policy prescription and or implementation on a given challenge can succeed without the input of community/individuals to which such policy prescription(s) are meant to support. Hence from prescription level to implementation level, all three actors (policy makers, implementers and recipients of policy outcomes) must network to the realization of effective policy prescription/delivery. Scharpf in Fischer and Miller supported this when he introduced the concept of policy networks which states the need for more weight to be given to processes of coordination and collaboration among separate but mutually dependent actors (policy makers' implementers (bureaucrats) and the citizens). The research revealed that the implementation of drought and desertification policy has not been effective since policy prescription was centrally done (top-down) without the input of implementers or recipients of outcomes.

Furthermore, the research revealed that policy implementers (bottom-up), who are bureaucrats, have failed to connect with recipients of policy at delivery points. Thus the research jettisons the top-down and bottom up theories of implementation since they could not satisfy a proper delivery of policy expected outcomes.

\section{Methodology}

\section{Population sampling/data collection}

Purposive sampling technique was adopted in choosing three states out of the six states of the North-east geo-political zone were selected for the study. The states were: Adamawa, Bauchi, Gombe. In the second stage, two local government areas were randomly selected from each of the States understudy study. Hence, a total of 6 local government areas were sampled. The last stage was a random selection of 200 farmers from each LGA, giving a total of 1200 respondents for the study. The study carried out interview sessions on local council authorities and leaders of community of stakeholder (farmers), senior member of agencies and committees set by federal and state government's ministries of environment and water resources.

An extensive search for existing data and records on implementation of drought and desertification issues in Nigeria was conducted. The secondary sources comprised of data assessed from local government offices, and Federal Ministry of Environment

\section{Findings}

The study observed that in the bid to combat drought and desertification the North-east, government among other action not captured on this study, adopted the following strategies:

\section{Awareness programs on drought and desertification}

Information is no doubt a key to combating drought and desertification. The interview conducted with government officials claim that awareness on threat of desertification is one strategy the federal government has adopted to raise the consciousness of the people on the effects of the twin menace drought and desertification. She does this using sustained radio and television jingles, print media campaigns, seminars, conferences and workshops. This helps especially on the early warning signal by government to prepare the mass on any impending drought scourge that might befall the zone.

\section{Tree planting and the ongoing campaign on desertification}

One of the strategies of combating drought and desertification is the planting of shelter-belt trees across the Sahara. These trees are meant to mitigate the effect of desertification on the zone. Seedlings of the trees are meant to be distributed to local farmers in the zone to plant.

\section{The trees planted are being nurtured by government officials}

When shelter belt trees are planted, it is expected that agents of government will tend to this tress and nurture then to maturity. This is part of the strategies adopted by government to see that efforts made at combating drought and desertification works.

\section{Host community's involvement in the tree planting exercise of government}

As part of policy implementation strategy is the involvement of host communities in the tree planting processes. This is important as it gives communities involved a sense of ownership and thus help to make them ensure the survival of such project.

\section{The pattern of tree planting}

Another aspect of the strategy is how trees are being planted. The cutting down of trees from time to time, either discriminately or indiscriminately, means that plans for replacement is important. And from government reports, tree planting is an annual event.

\section{Awareness on laws prohibiting the cutting down of trees}

Effective policy implementation strategies include also provision of requisite laws that will deter offenders from acting in a manner capable 
Citation: Nwokocha CO (2017) The Challenges Facing the Effective Implementation of Drought and Desertification Policy in North-East Geopolitical Zone of Nigeria. Arts Social Sci J 8: 289. doi:10.4172/2151-6200.1000289

Page 4 of 8

of destroying or limiting the effectiveness of such Policy or strategies put in place.

\section{Continuous provision of dams for farmers in the North-east}

The provision of dam for the irrigation of the zone especially farm lands is part of the implementation strategy adopted by the government to fight desertification in the North-east.

\section{Maintenance of dams by government as at when due}

Sequel to provision of dam for the control of drought, government is also obligated as part of policy strategy to maintain the dams.
Despite this strategies put in place, by government, one would wonder why there has not been a more positive response to the situation in terms of the level of food production from come from that zone. Further to the food insecurity, is also the issues arising from population explosion taking being the migration place in some of the communities within the zone due to the fact that people have to move to areas where they can find arable and aquatic life to support both their crop and life-stock farming. Thus this research questions what possible challenges there are in the process of achieving the strategies mentioned above. The tables below provides an empirical result on the issues that seem to mitigate on strategies put forward by government to combat drought and desertification the North-east geographical zone of Nigeria.

\begin{tabular}{|c|c|c|c|c|c|}
\hline & & Frequency & Percent & Valid Percent (\%) & Cumulative Percent (\%) \\
\hline \multirow[b]{6}{*}{ Valid } & Strongly Disagree & 17 & 2 & 2 & 2 \\
\hline & Disagree & 157 & 18 & 18 & 20 \\
\hline & Not Sure & 90 & 10.3 & 10.3 & 30.3 \\
\hline & Agree & 165 & 18.9 & 19 & 49.3 \\
\hline & Strongly Agree & 441 & 50.6 & 50.7 & 100 \\
\hline & Total & 870 & 99.9 & 100 & \\
\hline \multirow[b]{2}{*}{ Missing } & System & 1 & 0.1 & & \\
\hline & Total & 871 & 100 & & \\
\hline
\end{tabular}

Table 1: Respondents on host communities of government programs on irrigation dams being evidently involved in the program.

The Table 1 shows that respondents agree that host communities of irrigation Dam programs of government in the North-east zone should be evidently involved in the programs. The table shows that those who either strongly disagreed or disagreed to the statement accounts for
$20.0 \%$ consisting of 174 persons. While respondents who either agreed to the statement or strongly agreed account for $69.5 \%$ consisting of 616 persons. However, those who were unsure accounts for $10.3 \%$ consisting of 90 persons.

\begin{tabular}{|c|c|c|c|c|c|}
\hline & & Frequency & Percent & Valid Percent (\%) & Cumulative Percent (\%) \\
\hline \multirow[t]{6}{*}{ Valid } & Strongly Disagree & 39 & 4.5 & 4.5 & 4.5 \\
\hline & Disagree & 129 & 14.8 & 14.8 & 19.3 \\
\hline & Not Sure & 121 & 13.9 & 13.9 & 33.2 \\
\hline & Agree & 182 & 20.9 & 20.9 & 54.1 \\
\hline & Strongly Agree & 399 & 45.8 & 45.9 & 100 \\
\hline & Total & 870 & 99.9 & 100 & \\
\hline \multirow[t]{2}{*}{ Missing } & System & 1 & 0.1 & & \\
\hline & Total & 871 & 100 & & \\
\hline
\end{tabular}

Table 2: Respondents on poor funding of government programs is a major challenge to the combating of drought and desertification.

The irrigation dams are supposed to serve the people; as such areas where they need it most or where it will sustainably address their needs can only be identifiable by them. In other words, when they are engaged in the process of bringing it about, they will be able to channel it to more effective use. They farmers interviewed decried the ineffectiveness of the irrigation dams created in the some parts of the 
Citation: Nwokocha CO (2017) The Challenges Facing the Effective Implementation of Drought and Desertification Policy in North-East Geopolitical Zone of Nigeria. Arts Social Sci J 8: 289. doi:10.4172/2151-6200.1000289

Page 5 of 8

zone, as they could not effectively channel them to their farms, thus leading to distortion in the way the channels were made originally.

The Table 2 shows that poor funding is a major challenge to combating drought and desertification in the north-east zone. The result of the Table 2 shows that those who strongly disagree or disagree amounted $19.3 \%$, consisting of 168 persons. While those who either agree or strongly agree amounted to $66.7 \%$ consisting of 581 persons.
Those who were not sure accounted for $13.9 \%$ consisting of 121 persons, the issues of poor funding was identified in an interview with officers of the ministry of environment as a major challenge to combating of drought and desertification in Nigeria and in particular, the North-east. Some noted that since 2009, monies have not been released for tree planting exercise even in the north east.

\begin{tabular}{|c|c|c|c|c|c|}
\hline & & Frequency & Percent & Valid Percent (\%) & Cumulative Percent (\%) \\
\hline \multirow[t]{6}{*}{ Valid } & Strongly Disagree & 24 & 2.8 & 2.8 & 2.8 \\
\hline & Disagree & 148 & 17 & 17 & 19.8 \\
\hline & Not Sure & 152 & 17.5 & 17.5 & 37.2 \\
\hline & Agree & 296 & 34 & 34 & 71.3 \\
\hline & Strongly Agree & 250 & 28.7 & 28.7 & 100 \\
\hline & Total & 870 & 99.9 & 100 & \\
\hline \multirow[t]{2}{*}{ Missing } & System & 1 & 0.1 & & \\
\hline & Total & 871 & 100 & & \\
\hline
\end{tabular}

Table 3: Respondents on how government agents manage the trees planted by Government.

The Table 3 shows that government agents do not nurture the trees they plant to the level of protecting the environment. The respondent from the table shows that $19.8 \%$ consisting of 172 persons either strongly disagreed or disagreed to the statement that government agents do not nurture planted trees to the level of protecting environment. However, $62.7 \%$ consisting of 546 persons either strongly agreed or greed that government agents do not nurture the trees planted to maturity. Those who were not sure accounted for $17.5 \%$ involving 152 persons, a further understanding to this situation came from interview sessions conducted with some farmers in the zone. The farmers informed the researcher that there is common practice of neglect of duty by the agents of government who are meant to nurture the planted trees to maturity. The reason being that authorities do not come around to ask questions, and of cause the agents are adhoc workers to the ministry or to the local council, thus the persons has other things doing than to watch over plants.

\begin{tabular}{|c|c|c|c|c|c|}
\hline & & Frequency & Percent & Valid Percent (\%) & Cumulative Percent (\%) \\
\hline \multirow[t]{6}{*}{ Valid } & Strongly Disagree & 172 & 19.7 & 19.8 & 19.8 \\
\hline & Disagree & 167 & 19.2 & 19.2 & 39 \\
\hline & Not Sure & 173 & 19.9 & 19.9 & 58.9 \\
\hline & Agree & 170 & 19.5 & 19.5 & 78.4 \\
\hline & Strongly Agree & 188 & 21.6 & 21.6 & 100 \\
\hline & Total & 870 & 99.9 & 100 & \\
\hline \multirow[t]{2}{*}{ Missing } & System & 1 & 0.1 & & \\
\hline & Total & 871 & 100 & & \\
\hline
\end{tabular}

Table 4: Respondents on Citizens mismanagement of the dams created by government.

The Table 4 shows that the citizens of the north east mismanage the Dams created by government. The table of respondent here shows that $38.9 \%$ of respondent consisting of 339 person, either strongly disagreed or disagreed that the people of North east zone mismanages the Dams created by government. Those who either strongly agreed or agreed to the statement amounted to $41.5 \%$ consisting of 358 persons. However $19.9 \%$ consisting of 173 persons were not sure. It is important here to make reference to the findings of the interview carried out with some farmers, which established that what are being mismanaged by the 
Citation: Nwokocha CO (2017) The Challenges Facing the Effective Implementation of Drought and Desertification Policy in North-East Geopolitical Zone of Nigeria. Arts Social Sci J 8: 289. doi:10.4172/2151-6200.1000289

Page 6 of 8

citizens of the north are not actually the Dams, but channels through which the water from the Dams gets to the areas where it is needed.

\begin{tabular}{|c|c|c|c|c|c|}
\hline & & Frequency & Percent & Valid Percent (\%) & Cumulative Percent (\%) \\
\hline \multirow[t]{6}{*}{ Valid } & Strongly Disagree & 59 & 6.8 & 6.8 & 6.8 \\
\hline & Disagree & 247 & 28.4 & 28.4 & 35.2 \\
\hline & Not Sure & 141 & 16.2 & 16.2 & 51.4 \\
\hline & Agree & 291 & 33.4 & 33.5 & 84.9 \\
\hline & Strongly Agree & 131 & 15 & 15.1 & 100 \\
\hline & Total & 869 & 99.8 & 100 & \\
\hline \multirow[t]{2}{*}{ Missing } & System & 2 & 0.2 & & \\
\hline & Total & 871 & 100 & & \\
\hline
\end{tabular}

Table 5: Respondents on citizens cutting down Trees planted by government indiscriminately.

The Table 5 shows that people in the north-east zone cut down trees planted by government indiscriminately. The table shows that $35.2 \%$ consisting of 306 persons who either strongly disagreed or disagreed. While $48.4 \%$ consisting of 422 persons either strongly agreed or agreed that the people of the north east indiscriminately cut down trees planted by government. Those who were not sure amounted to $16.2 \%$ consisting of 141 persons, in an interview with the local farmers in the north-east it was revealed that their source of cooking is from trees they cut from the bush. They also agreed to the fact that individuals cut down trees from the bushes for commercial purposes which includes: making of charcoal and or chopping the woods into fire woods and shipping them off for sale.

\begin{tabular}{|c|c|c|c|c|c|}
\hline & & Frequency & Percent & Valid Percent (\%) & Cumulative Percent (\%) \\
\hline \multirow[t]{6}{*}{ Valid } & Strongly Disagree & 85 & 9.8 & 9.8 & 9.8 \\
\hline & Disagree & 127 & 14.6 & 14.6 & 24.4 \\
\hline & Not Sure & 190 & 21.8 & 21.8 & 46.2 \\
\hline & Agree & 234 & 26.9 & 26.9 & 73.1 \\
\hline & Strongly Agree & 234 & 26.9 & 26.9 & 100 \\
\hline & Total & 870 & 99.9 & 100 & \\
\hline \multirow[t]{2}{*}{ Missing } & System & 1 & 0.1 & & \\
\hline & Total & 871 & 100 & & \\
\hline
\end{tabular}

Table 6: Respondent on rain fall as a challenge to tree planting.

The Table 6 shows that rainfall is a major challenge to tree planting in the northeast zone. The respondents who either strongly disagree or disagreed to the statement that rainfall is a major challenge to tree planting amounted to $24.4 \%$ consisting of 212 persons. While those who either strongly agreed or agreed amounted to $53.8 \%$ consisting of 568 persons. Those who were not sure amounted to $21.8 \%$ consisting of 190 persons, in an interview with local council environmental authorities, it was revealed that one of the challenges of tree planting in the north-east is that when there is low rainfall, the trees will not be able to survive. Also when there is high rainfall, flood ensues and washes away soil, thus not allowing the needed soil nutrient that the trees require to grow.
The Table 7 shows that the Dams that exist in the zone are not maintained as at when due. This shows in the response of respondents. Respondent who either strongly disagree or disagree to the statement that have continually been maintained by government as at when due consist of $54.5 \%$ of the total respondents amounting to 473 persons. While $24.4 \%$ amounting to 215 persons respondents either agreed or strongly agreed to the statement. However, $20.8 \%$ consisting of 181 persons were not sure. Again while interviewing farmers in the zone, what was obviously not maintained were the channels of irrigation that move water from the Dams to the farm lands. The effect is that crops on farm lands struggle to make produce. This then leads to shortage in food coming from this zone to other parts of the country. 
Page 7 of 8

\begin{tabular}{|c|c|c|c|c|c|}
\hline & & Frequency & Percent & Valid Percent (\%) & Cumulative Percent (\%) \\
\hline \multirow[t]{6}{*}{ Valid } & Strongly Disagree & 166 & 19.1 & 19.1 & 19.1 \\
\hline & Disagree & 308 & 35.4 & 35.4 & 54.5 \\
\hline & Not Sure & 181 & 20.8 & 20.8 & 75.3 \\
\hline & Agree & 91 & 10.4 & 10.5 & 85.7 \\
\hline & Strongly Agree & 124 & 14.2 & 14.3 & 100 \\
\hline & Total & 870 & 99.9 & 100 & \\
\hline \multirow[t]{2}{*}{ Missing } & System & 1 & 0.1 & & \\
\hline & Total & 871 & 100 & & \\
\hline
\end{tabular}

Table 7: Respondents on the maintenance of dams by government as at when due.

\section{Challenges of implementation}

The crux of this research work is to establish whether or not there are challenges inhibiting the smooth implementation of the policy on Drought and desertification in the North-east geographical zone of Nigeria. From the tables above, the following analysis can be deduced.

\section{Poor funding of government programs is a major challenge}

Another problem to implement as reviewed in the literature is the issue of poor funding. Table 7 of respondent disclosed that $70.2 \%$ (612) of respondent are of the opinion that governments do not properly fund projects meant for combating drought and desertification, thus abandonment of program or projects. Ikelegbe [8]; Dick [9] and Ugwuanyi and Emma [10], corroborated the opinion of the respondent when they commented that poor funding is one of the banes of drought and desertification policy implementation. In an interview with officers of the ministry of environment poor funding was identified as a major challenge to combating of drought and desertification in Nigeria and in particular, the North-east. Some noted that since 2009, funds meant for combating tree planting exercise in the north east have only been released on paper. Furthermore, challenges of poor funding could be seen in the number of workers or agents attending to the trees planted (in terms of nurturing them) or following up on the activities of those vandalizing the dams as well as those indiscriminately felling the trees.

\section{Government agents and management of the trees planted by government}

Part of the challenge of implementation of policy as reviewed in the literature was the challenge of bureaucrats. The survey carried out in the North-east was to establish the effectiveness of government agents in the management of the trees planted to combat drought and desertification. Table 7, respondent disclosed that $62.7 \%$ (546) of respondent are of the opinion that government agents do not properly manage the trees planted by government to protect the zone from drought and desertification. This confirms the submission of Ugwuanyi and Chukwemeka [9], who concluded that a major obstacle to implementation of public policy is Public Bureaucracy. Further understanding to this situation came from interview sessions conducted with some farmers in the zone. The farmers corroborated the opinion of the respondent that there is common practice of neglect of duty by agents of government who are meant to nurture the planted trees to maturity.

\section{Citizens' mismanagement of the dams created by government}

Among the issues of the challenges in fighting drought and desertification is the mismanagement of the dams created by the government. Official claim the dams provided are by government are often mismanaged by the citizens. The result of the survey, disclosed that $41.5 \%$ (358) of respondent shows that indeed the dams are mismanaged by citizens. The literature reviewed established that in UNCCD Report, [11] Desertification occurs because dry land ecosystems are extremely vulnerable to over-exploitation and inappropriate land use and improper irrigation practices all can undermine the productivity of the land. It is also important here to make reference to the findings of the interview carried out with some farmers, which established that what is being mismanaged by the citizens of the north is not actually the Dams, but channels through which the water from the Dams, gets to the areas where it is needed the farmlands. There is also a significant relationship between this revelation to the submission of Mohammed (2012) suggested that it is not unlikely that human attempts to exploit the resources of the semiarid ecosystems of Nigeria, especially in these recent times of severe and persistent drought and its concomitant desertification, may have enhanced the rate of ecological damage in the North-east geo-political Zone on Nigeria.

\section{Citizens' fall down trees planted by government indiscriminately}

A critical issue on implementation is the action of the citizens towards government projects aimed at combating desertification. Thus survey on Table 7, revealed that $48.4 \%$ (422), citizens of the North-east, engage in indiscriminate cutting down of trees. This supports the submission of Elazeh, that indiscriminate falling of trees in the desert prone areas of the North is an age long tradition since it provided firewood for the daily use of the people. However, he buttressed the 
Citation: Nwokocha CO (2017) The Challenges Facing the Effective Implementation of Drought and Desertification Policy in North-East Geopolitical Zone of Nigeria. Arts Social Sci J 8: 289. doi:10.4172/2151-6200.1000289

Page 8 of 8

fact that it is posing serious threats to the collective fight against desertification.

\section{Rain fall as a major challenge to tree planting}

Survey set out to ascertain the arguments that rainfall is a major challenge to effective implementation of drought and desertification policy. The result on Table 6 showed that 53.8\% (568) were of the opinion that rain fall is a major challenge to tree planting exercise in the zone. Thus underscoring the report that the location, Northern Nigeria is situated in the semi-arid areas with average annual rainfall or less than $600 \mathrm{~mm}$ bordering on the Sahara desert and as such experiences low rainfall annually [12]. Here, respondents tend to agree with government officials on the challenges of combating drought and desertification in Nigeria and in particular the North-east.

\section{Conclusion}

Conclusively, from the foregoing the research, the research advocates that following actions must be put in place to curb the challenges of implementing the policy on drought and desertification in the North-east geographical zone and by extension, other zones in the country affected by the twin menace.

One cannot over emphasis the place of citizen participation at the implementation stage of every project initiated by government to curb these menace. This is important as it gives a sense of ownership to the entire stakeholder.

Education is also a key at the implementation stage of each program on the amelioration of drought and desertification in Nigeria. This will help put the people in shape to know how to manage the infrastructure government is putting in place to manage the challenges. The means of putting forward information is also very important. This is because most of the people affected are local farmers who might not be available at times when the can here from the radio new on actions that government wants to take, thus the need to put these people in cooperatives and educate them in the language they can understand.

An alternative to firewood for cocking in the zone must be provided to curb the indiscriminate cutting down of trees thereby exposing the people to desert encroachment. A special joint Taskforce of Federal, state and policing of the forests must be put in place as a matter of urgency to stop the indiscriminate falling of the trees.

There is the need for effective monitoring and evaluation of the activities of government agents deplored implement these strategies meant to combat the twin menace. From the foregoing, it evident that proper monitoring has not been in place as such the people are not getting the needed benefit from the action of government toward curbing the Drought and Desertification menace.

\section{References}

1. UNCCD (2005) Combating desertification and mitigating the effects of drought in Nigeria. National Report on the Implementation of the United Nations.

2. Mohamed N (2015) Desertification in Northern Nigeria: Causes and implications for national food security. Journal of Social Sciences and Humanities 3: 22-31.

3. Burmamu BR, Timtere P, Aliyu HH (2013) Desertification and soil erosion: dual effects of deforestation in jada local government area of Adamawa state, Nigeria. International Journal of Scientific Engineering and Technology 2: 1156-1161.

4. Emodi E (2013) Drought and desertification as they affect Nigerian environment. Journal of Environmental Management and Safety 4: 45-54.

5. Kogi Reporters.com

6. Idris-Nda A (2005) Groundwater potential of part of Kushaka Schist belt of North-Central Nigeria. Water Resource 16: 90-95.

7. Mackey RE (2008) Street level bureaucrats and the shaping of university housing policy and procedures.

8. Ikelegbe A (2006) Public policy analysis: concepts, issues and cases. In: Barton L (ed.) Disability and Dependency. Falmer Press, London.

9. Dick I (2003) Contemporary public administration: The Nigerian perspective. John Jacob Classic Publishers, Enugu.

10. Ugwuanyi BI, Chukwuemeka EO (2013) The obstacles to effective policy implementation by the public bureaucracy in developing Nations: the case of Nigeria. Singaporean Journal of Business Economics, and Management Studies 1: 34-43.

11. UNCCD Guidelines (2014) The United Nations convention to combat desertification and drought.

12. Folaji MB (2007) Combating environmental degradation in Nigeria: a case study of desertification in Kano State. The Armed Forces Command and Staff College, Jaji. 